\title{
Health Promoting Special Schools for Children and Young People With Intellectual Disabilities in Poland: Development of Standards and Self-Evaluation Procedures
}

\author{
Magdalena Woynarowska-Sołdan ${ }^{1}$ and Dorota Danielewicz ${ }^{2}$ \\ ${ }^{1}$ Public Health Division, Faculty of Health Sciences, Medical University of Warsaw, Poland \\ 2Institute of Psychology, The Maria Grzegorzewska University, Warsaw, Poland
}

\begin{abstract}
HOW TO CITE:
Woynarowska-Sołdan M.,

Danielewicz, D. (2020).

Health Promoting Special

Schools for Children and Young

People With Intellectual

Disabilities in Poland:

Development of Standards and Self-Evaluation Procedures. International Journal of Special

Education, 35(2), 29-40

CORRESPONDING AUTHOR:

Dorota Danielewicz;

ddanielewicz@aps.edu.pl

DOI:

https://doi.org/10.52291/

ijse.2020.35.11

COPYRIGHT STATEMENT:

Copyright: (C) 2020 Authors.

Open access publication under

the terms and conditions

of the Creative Commons

Attribution (CC BY)

license (http://creativecommons.

org/licenses/by/4.0/).
\end{abstract}

\section{ABSTRACT}

The purpose of the study was to present the process and results of developing standards and self-evaluation procedures for health promoting special schools (HPSS) for children with intellectual disabilities. The work was undertaken in order to address the needs of special schools interested in establishing a health promoting school (HPS). We used following methods: 1) Preparation: interviews with principals and teachers at 8 special schools, as well as regional HPS network coordinators, visits to 4 schools; 2) Development of HPSS project standards, self-evaluation procedures and tools: consultations with representatives of 8 schools and with regional coordinators; 3) Pilot study of HPSS the self-evaluation procedure and tools at 8 schools and development of a finalised version: direct observation, document analysis, interviews with selected participants, survey studies of school staff and students' parents, testing students using one of the following methods: "Draw and write", "Draw and tell", conversation or written response. The study included people supporting HPS on a national and regional level, school principals and health promotion coordinators from special schools for students with intellectual disabilities. The pilot study was conducted on a group of 341 teaching staff, 148 non-teaching staff, 468 parents of students, and 435 students. The analysis of the study's reports and consultations with school principals and health -promotion coordinators from participating schools guided the development of the final version of standards, in addition to the associated model of HPSS and self-evaluation procedure along with a set of tools to measure the accomplishment of the standards. The HPSS standards and self-evaluation procedure were approved by the Ministry of National Education and officially disseminated, with special schools gaining the opportunity to apply for the Health Promoting School National Certificate. The self-evaluation element of HPSS makes it possible to improve the activities of special schools with respect to health promotion while encouraging collaboration and exchange of ideas with regular schools.

Keywords: special schools; intellectual disability; health promotion; health promoting school; standards; self-evaluation 


\section{INTRODUCTION}

Health promoting school (HPS) is a programme/approach based on the health promotion concept defined as; the process of enabling people to increase control over, and to improve, their health (World Health Organization [WHO], 1986). In this framework, health is actively created by people in daily life, in all settings, i.e. places where they live, study, work, relax, and play (settings approach). One such setting is school with it's community of teachers, other teaching and non-teaching staff, students, and their parents. Promoting health requires integration of two types of activity: individual actions of people striving for a healthy lifestyle and community initiatives that create a supportive physical and social environment for health. The efficacy of these activities depends on participation and involvement of as many members of a given community as possible. Health promotion programmes are implemented "with the people", rather than "for the people". School programmes require participation of students (as far as possible), teachers, and non-teaching staff, as well as the involvement of students' parents.

HPS is a model where the health and well-being of students and teaching/non-teaching staff are addressed in a systematic and pre-planned way (Schools for Health in Europe network [SHE], 2013). HPS is based on a whole school approach to health promotion, which goes far beyond offering health education on various aspects of health. This approach is focused on: integrating health promotion with its core activities, including the curriculum; creating healthy school policies and environments, building partnerships with the social and family settings of students and developing students' life skills and competences (Clift \& Jensen, 2005, as cited in: Busch, Laninga-Wijnen, Schrijvers \& De Leeuw, 2017). The establishment of HPSs is a grass-roots movement ("bottom-up"), which means that the school community itself decides to undertake health promoting activities and evaluate their outcomes.

In Poland, the HPS programme/approach began in January 1992 as part of a 3-year pilot project initiated by 'WHO/EURO' at primary schools in the Czech Republic, Slovakia, Poland, and Hungary. In the same year, Poland became one of the first members of the European Network of Health Promoting Schools, ENHPS (Stewart Burgher et al., 1999), and since 2007 has been a member of the Schools for Health in Europe network (SHE).
Over the past three decades the HPS programme has achieved nationwide reach. This became possible by establishing (in collaboration with the healthcare sector) structures to support schools in their health-promoting activities at the national, voivodeship and county/municipality level (Woynarowska \& Sokołowska, 2006). The coordinating role in the structure is played by regional HPS networks operating since 2006 across all voivodeships. The membership in 2019 included over 3,200 schools of various types and preschools. The education sector leads the way in the popularisation and support for HPSs. A significant incentive to improve the quality of schools' functionality and encourage them to long-term, systematic work, as well as a way to reward effort and accomplishments was the establishment in 2007 of the Health Promoting School National Certificate. The certificate is granted by the Minister of National Education at the request of the certificate's Chapter which evaluates how a given school meets the predetermined requirements, including self -evaluation findings (Woynarowska \& Sokołowska, 2009; Ośrodek Rozwoju Edukacji [ORE], 2020). To date, 364 schools and preschools have been certified.

The development of HPS in Poland was closely linked with the evolution of the concept in Europe. It's main directives were set by the resolutions/positions of four European Conferences on Health Promoting Schools (Halkidiki, 1997; Egmond, 2002; Vilnus, 2009; Odense, 2014) (Woynarowska-Sołdan, 2015). Over the last decade, the course of HPS activities was guided by the pillars and values of the approach adopted by the SHE network (SHE, 2009). Their relevance was reaffirmed in the resolution of the 5th European Conference that took place in 2019 in Moscow (Dadaczynski et al., 2019).

The HPS concept and implementation strategy in Poland were adapted for the unique circumstances associated with among others, the education system, sociocultural factors, the country's economic standing and the plethora of changes that have taken place in these areas in the period of political transformation. The last modifications to the model, standards and self-evaluation tools were introduced in 2019 (Woynarowska \& WoynarowskaSołdan, 2019). Since the beginning of the programme, particular attention was paid to systemic action planning and self-evaluation of it's effects (Woynarowska, 2013). A new challenge was to undertake (within the HPS framework) activities to promote the health of teachers and non-teaching staff. School is not only a place of learning for students; it is also a workplace for many employees. 
The possibilities of taking such actions, implementation strategies and outcomes were evaluated in Poland as part of the project "Promoting health of staff members in health promoting schools" (2012-2015), carried out at 21 schools (Woynarowska-Sołdan, 2016; Woynarowska-Sołdan, 2018). It's theoretical underpinnings included: the concept of health promotion with its specific approaches and values; the fundamental theories of the settings approach and concepts for changing health-related behaviour (Woynarowska-Sołdan, 2016). The inclusion of staff -oriented health promotion in the scope of HPS activities is a unique feature of these schools and one of the aspects that distinguish them from other schools.

Similarly to other European countries, the HPS model, its standards, as well as the indicators and tools used for self-evaluation in Poland were originally designed for mainstream schools in which students are important participants/partners in health promotion activities. In the last decade there has been growing interest in the HPS approach among special schools that provide education to children and adolescents with various degrees of intellectual disability. These students are the largest group of students at special schools and educational facilities (Główny Urząd Statystyczny [GUS], 2019). A number of special schools have made attempts to adapt HPS standards to their needs and capabilities. Some were members of regional HPS networks, but their employees felt marginalized or even discriminated against in the movement, since the schools were ineligible for the Health Promoting School National Certificate. This was due to the lack of self-evaluation standards and tools specifically adapted for these institutions. The greatest challenge was getting students with varying degrees of intellectual disability and other coexisting disorders to take part in the self-evaluation of health-promoting activities at school.

HPS supporters were aware of these inequalities, especially that equity and inclusion are listed among the five core values of HPS (SHE, 2009). Many regional HPS network coordinators were advocating for special schools. However, developing standards and self-evaluation procedures in special schools for students with intellectual disabilities seemed challenging due to the wide range of developmental and health disorders exhibited in these students and their limited ability to participate in health promoting activities and their evaluation. A breakthrough in this area was the development and verification of standards and tools to self-evaluate their attainment in kindergartens (Woynarowska-Sołdan \& Woynarowska,
2017), which enabled them to apply for a Health Promoting Kindergarten National Certificate. Encouraging new ideas and solutions emerged during this process.

\section{The purpose of this paper is to present:}

- The development process of standards in addition to the self-evaluation procedure and tools for health promoting special schools for children and adolescents with mild, moderate and severe intellectual disabilities and multiple disabilities (one being intellectual disability), hereinafter referred to as health promoting special schools (HPSS);

- The outcomes of this process: the basic components of the HPSS concept, including it's standards, model and self-evaluation procedure and tools adopted in Poland and approved by the Ministry of National Education.

\section{STAGES AND METHODS}

The process of preparing the HPSS standards and self-evaluation procedure undertaken between 2018 and 2020 included three stages: preparation - development of draft standards, self-evaluation procedure and tools; a pilot study of the draft HPSS self-evaluation procedure and tools; and fine-tuning their final versions.

\section{- Preparation}

The purpose of this stage was to assess the number of special schools interested in establishing HPS and the needs and expectations of principals and health promotion coordinators at those schools. Those being that had already initiated health promotion efforts, as well as their experiences to date. The following methods were used:

- Interviews with regional coordinators of HPS networks that already included specials schools and document analysis (lists of special schools in the networks).

- A focus group with principals and school coordinators for health promotion from 8 special schools belonging to the HPS network.

- On-site visits to 4 special schools for students with intellectual disabilities: observing how the school and students functioned, conversations with principals and teachers.

\section{- Preparing draft HPSS standards and self-evaluation procedure and tools}

This stage included:

- Developing the four HPSS standards. Their contents were subjected to team analysis in order to agree on the final version and consultations with school principals 
and coordinators at 8 schools, furthermore collecting opinions of HPS network regional coordinators.

- Preparing a draft of the self-evaluation procedure (including toolkit) to achieve HPS standards and assess their outcomes. Modifying of the self-evaluation procedure and tools used at mainstream HPSs and adapting them to the needs and capabilities of special schools.

\section{- Pilot study of HPSS self-evaluation procedure and tools at selected special schools; preparing their final versions}

This stage included:

- Surveys at 8 special schools to assess: 1) clarity of statements in questionnaires and evaluation sheets; 2 ) appropriateness of proposed tools for the specifics of special schools; 3) how difficulty level and time required to test individual aspects of health-promotion activities conducted at special schools differed. The assessment employed qualitative and quantitative methods specified in the self-evaluation procedure: direct observation, document analysis, interviews with selected participants, survey studies of school staff and students' parents, testing students using a choice of one of the following methods: "Draw and write", "Draw and tell", conversation or written response. The schools received materials to conduct the research, including: 1) a description of the self-evaluation procedure; 2) questionnaires for the three groups of staff members and for students' parents; 3) evaluation sheets for each standard and activity outcomes; 4) guidelines on the methods for conducting each test; 5) a set of study protocols using each tool to record the progress of the study, number of subjects tested, problems understanding statements in questionnaires, opinions, and suggested improvements. The research at the schools was conducted by members of the health promoting team or the appointed evaluation team. The lead investigator was the school coordinator for health promotion, supported by the principal. During the pilot study, school coordinators collaborated closely with regional HPS network coordinators.

- Analysis of research findings and experience from the pilot study: analysing study reports, results of evaluation sheets for all staff members and parents, students' input, consultations with school principals and health promotion coordinators at the 8 pilot study schools.

- Preparation of the final version of HPSS standards and self-evaluation procedure and tools: consultations with schools participating in the pilot study and HPS network regional coordinators.

\section{PARTICIPANTS}

A number of people contributed to the development of HPSS standards and self-evaluation procedure, including: 1) The SHE network National Coordinator and the HPS country coordination team operating at the Centre for Education Development (Ośrodek Rozwoju Edukacji, ORE) supervised by The Ministry of National Education; 2) HPS regional network coordinators; 3) The school principals and coordinators for health promotion from the 8 special schools/educational centres for students with intellectual disabilities associated in the HPS network.

The pilot study involved the communities of 8 schools/ special education centres for students with mild, moderate or severe intellectual disabilities and multiple disabilities (one being intellectual disability) in four voivodeships. The schools had been part of voivodeship HPS networks for 3-5 years and volunteered for the pilot study. Research for the pilot study was conducted on various school community groups. The overall participant population included: 341 teaching staff members (teachers and other individuals working with students), 148 non-teaching staff, 468 parents of students and 435 students.

\section{PROCESS RESULTS}

The analysis of study protocols and consultations with representatives of pilot schools guided the development of the final version of the standards with the associated model of HPSS and the self-evaluation procedure along with a set of tools to measure the accomplishment of standards. Their characteristics along with samples of finalised tools (questionnaires, evaluation sheets and student's responses) are provided below. These samples offer better insight into the tools than a mere description. Detailed information about the self-evaluation procedure and the set of tools and instructions for testing and interpretation of results is available online on the ORE website (Woynarowska-Sołdan et al., 2020).

\section{Standards and model of a health promoting special school}

It was assumed that a health promoting special school is one that, in collaboration with students' parents and local community:

- Creates a social and physical environment favourable to health and well-being of the school community in a systematic and deliberate manner. 


\begin{tabular}{|c|c|}
\hline Standards & Dimensions \\
\hline $\begin{array}{l}\text { I. The school policy, school structure, } \\
\text { organisation and conditions enhance } \\
\text { the health and participation of the school } \\
\text { community in activities related to health } \\
\text { promotion, as well as their effectiveness } \\
\text { and long-term implementation. }\end{array}$ & $\begin{array}{l}\text { - Including health promotion in documents, as well as in school work and life. } \\
\text { - Structure for implementing the HPS programme. } \\
\text { - Training, informing and making available information about the HPS concept } \\
\text { - Health promotion activities planning and evaluation, as well as record-keeping. }\end{array}$ \\
\hline $\begin{array}{l}\text { II. The school's social environment fosters } \\
\text { health and well-being of students, teachers } \\
\text { and non-teaching staff, as well as parents }\end{array}$ & $\begin{array}{l}\text { - Creating opportunities for teachers, other teaching and non-teaching staff, and } \\
\text { parents to take part in school life. } \\
\text { - Relationship with and support from the school management. } \\
\text { - Relations between staff members. } \\
\text { - Relations between staff and students' parents. } \\
\text { - How parents perceive the way teachers treat their children. } \\
\text { - How parents perceive their children's attitude towards the school. }\end{array}$ \\
\hline $\begin{array}{l}\text { III. The school organizes health education } \\
\text { for students and helps them practice } \\
\text { healthy behaviours in daily life. }\end{array}$ & $\begin{array}{l}\text { - Health education conducted at school. } \\
\text { - Ensuring healthy nutrition for students at school and helping them practice heal- } \\
\text { thy eating behaviours. } \\
\text { - Helping students practice bodily health behaviours. } \\
\text { - Acting to encourage students' physical activity. } \\
\text { - Enabling students to practice behaviours that improve their safety. } \\
\text { - Introducing education about the students' sexuality. }\end{array}$ \\
\hline $\begin{array}{l}\text { IV. The school acts to raise the competences } \\
\text { of educators and students' parents } \\
\text { with respect to healthy lifestyle and health } \\
\text { education of students. }\end{array}$ & $\begin{array}{l}\text { - Developing staff members' skills with respect to caring for their health } \\
\text { and the health education of students. } \\
\text { - Helping parents develop skills with respect to caring for their own health, } \\
\text { providing health education for their children and coping with parenting challenges. }\end{array}$ \\
\hline
\end{tabular}

- Supports students and educators in developing their competences in enhancing health throughout their lifetimes.

Four HPSS standards were agreed upon (Tab. 2). Some 2-6 dimensions were established for each standard, and 2-10 indicators for each dimension in the form of statements specifying the features evaluated in a given dimension. To enumerate all indicators would go beyond the scope of this paper. They are available online on the ORE website (Woynarowska-Sołdan et al., 2020).

\begin{tabular}{c|c}
\hline Level 3 & Outcome evaluation \\
\hline Level 2 & Standards II, III, IV \\
\hline Level 1 & Standard I \\
\hline
\end{tabular}

Figure 1. Model of a health promoting special school

The short-form standards are included in the HPSS model (Fig. 1). The model consists of three levels. Level 1 (bottom) concerns the conditions necessary to establish a HPS and is addressed by standard I. Level 2 (middle) presents the key areas of HPSS activities specified in standards II, III, and IV. The standards for level 3 "Expected outcomes" cannot be established, however, their evaluation is included.
It was assumed that the expected outcome of HPSS activities (Fig. 1) should be: improved well-being of school community members and their engagement in pro-health activities while learning/working at school and later in life (including by offering health education to students and staff). The evaluation of these outcomes can only be approximate, since the health and well-being of individuals depends on multiple factors and only some of them are associated with attending/working at school. Introducing lifestyle changes directly affecting health is a longterm process that depends, among other things, on motivation, ability, and support. Due to the specific nature of special schools, it was decided that outcomes may only be studied in school staff and, to some extent, students' parents.

\section{Self-evaluation procedure}

Self-evaluation was designed on the basis of the model and standards of HPSS. The aim of self-evaluation is to determine:

- to what extent the school complies with the four standards, i.e. the desired quality which HPSSs should be striving for?

- what results have been achieved so far with respect to the well-being of the school's community and activities to promote health undertaken by its staff and students' parents? 
Self-evaluation processes are initiated and supervised by the school coordinator for health promotion and the school health promotion team (which can appoint a self-evaluation team consisting of its members). Membership in this team should include 4 to 6 experienced teaching and non-teaching staff members with in-depth knowledge of the school and a willingness to work together. Clear division of tasks and ongoing support from the school principal are essential.

Study participants (subjects) are:

- Full-time or part-time employees with at least 2 years work experience at a given school including: teachers, other specialists working with students at the school and non-teaching staff.

- Parents of students attending the school for at least 2 years.

- Students.
Self-evaluation assessments follow the Action Research paradigm commonly used in education systems worldwide. This research method helps change established practices. Practitioners (e.g. teachers, principals) assume the double roles of researchers and agents of change (Czerepaniak-Walczak, 2010; McAteer, 2013).

The following methods are used to self-evaluate HPS activities:

- Direct observation: e.g. site inspection of premises, review of equipment, observation of students' and other people's behaviour.

- Document analysis: e.g. the school policy, records of the health promotion team (including action plans and evaluation reports), content posted to the school's website and message board.

- Interviews with selected individuals: e.g. the school principal, teachers, cafeteria staff, superintendent and school nurse.

\section{QUESTIONNAIRE FOR TEACHERS WHO ARE CLASS TEACHERS}

We would like to find out what you think about certain aspects of our school. This way we might learn about it's strengths and weaknes ses in order to improve it. The questionnaire is anonymous. Please answer honestly.

\begin{tabular}{|c|c|c|c|c|}
\hline $\begin{array}{l}\text { Below is a list of statements. Read each statement carefully and decide whether you agree with it. } \\
\text { Put X in one box next to each statement }\end{array}$ & Yes & $\begin{array}{l}\text { Rather } \\
\text { yes }\end{array}$ & $\begin{array}{l}\text { Rather } \\
\text { no }\end{array}$ & No \\
\hline \multicolumn{5}{|l|}{ Setting for creating a health promoting school } \\
\hline \multicolumn{5}{|l|}{ - At the school where I work, health and well-being are considered important } \\
\hline \multicolumn{5}{|l|}{$\begin{array}{l}\text { - There are initiatives at the school aimed at promoting employees' health (e.g. training/workshops } \\
\text { on health and healthy living, we are encouraged to take care of our health, } \\
\text { there are physical activities organised for the staff) }\end{array}$} \\
\hline \multicolumn{5}{|l|}{ - I was thoroughly informed about the health promoting school concept } \\
\hline \multicolumn{5}{|l|}{ Social climate at the school } \\
\hline \multicolumn{5}{|l|}{ - The school management asks me for my opinions about the life and functioning of the school } \\
\hline \multicolumn{5}{|l|}{ - My opinions about the life and functioning of the school are taken into account } \\
\hline \multicolumn{5}{|l|}{ - I have good relations with the school management } \\
\hline \multicolumn{5}{|l|}{ - I feel appreciated by the school management } \\
\hline \multicolumn{5}{|l|}{ - I get constructive feedback about my work from the school management } \\
\hline \multicolumn{5}{|l|}{ - I receive support from the school management whenever I need it } \\
\hline \multicolumn{5}{|l|}{ - I have good relations with other teachers } \\
\hline \multicolumn{5}{|l|}{ - Other teachers willingly work with me } \\
\hline \multicolumn{5}{|l|}{ - I get support from other teachers whenever I need it } \\
\hline \multicolumn{5}{|l|}{$\begin{array}{l}\text { - My relations with non-teachers who work with students (e.g. psychologist, speech therapist, } \\
\text { physiotherapist) are good }\end{array}$} \\
\hline \multicolumn{5}{|l|}{ - I am on good terms with non-teaching staff } \\
\hline \multicolumn{5}{|l|}{ - I am on good terms with students' parents } \\
\hline \multicolumn{5}{|l|}{ - Most parents work with me when it comes to their children } \\
\hline - I can count on students' parents' assistance when I need it & & & & \\
\hline
\end{tabular}

*The thin grey horizontal lines separate the dimensions of the school's social climate listed in Table 2. 
- Survey studies of teaching and non-teaching staff, and parents of students.

- Testing students using a choice of one of the following methods: "Draw and write", "Draw and tell", conversation or written response.

Research instruments include questionnaires for staff and students' parents, and evaluation sheets for each standard and activity outcome. Detailed instructions have been developed regarding the evaluation procedure and the processing of its results. The instruments are complex and contain several elements. Below are brief descriptions and excerpts from the instruments.

To collect the opinions of adult members of the school community, questionnaires were designed for: 1 ) teachers who are class teachers $(\mathrm{CT}) ; 2)$ other teachers and specialists working with students at the school $(\mathrm{OTaS}) ; 3)$ non-teaching staff (NTS) and 4) students' parents $(\mathrm{P})$. They contain statements relating to all standards and outcomes; participants are asked to indicate how much they agree with them. For illustration, the following two excerpts from the questionnaire for class teachers with indicators for standards I and II (Fig. 2) and outcomes (Fig. 3) are provided below.

The following formula is used to convert the rates of yes and rather yes response (preferred state) into points in each group of respondents: $91-100 \%=5$ pts, $75-$ $90 \%=4$ pts, $60-74 \%=3$ pts, $59 \%$ or less $=2$ pts. Only yes answers are counted for the section titled "What have you done for your health in the past 12 months?" A positive (preferred) result is the rate of at least $60 \%$. The decision on changing that rate is at the discretion of the evaluation team and takes into account the conditions and actions undertaken at a given school.

In addition, each questionnaire contains two open questions: for the staff: What factors contribute to you feeling well working at this school? What makes you feel bad working at this school?; for students' parents: What makes you feel well when you are at your child's school, What makes you feel bad when you are at your child's school?.

It was agreed that part of self-evaluation of HPSS should be to test students' opinions about what they liked and what they did not like at their school. These opinions may provide information on how students perceive the school's social climate (Standard II). For this research, a qualitative method and the choice of the following techniques (sample responses in figures 4-7) were proposed:

- Conversation with the student: Tell (show) me what you like and do not like at school.

- "Draw and tell": What do you like and not like at school? (the student makes a drawing on the subject

\begin{tabular}{|c|c|c|c|c|}
\hline & Yes & $\begin{array}{l}\text { Rather } \\
\text { yes }\end{array}$ & $\begin{array}{c}\text { Rather } \\
\text { no }\end{array}$ & No \\
\hline \multicolumn{5}{|l|}{ Well-being at school } \\
\hline \multicolumn{5}{|l|}{ - I usually feel well working at school } \\
\hline \multicolumn{5}{|l|}{ - I like working at this school } \\
\hline \multicolumn{5}{|l|}{ - I would recommend this school as a friendly workplace } \\
\hline $\begin{array}{l}\text { What have you done for your health in the past } 12 \text { months? } \\
\text { Below are examples of actions that improve health and well-being. Think if you have undertaken } \\
\text { such activities in the past } 12 \text { months. Put } X \text { in one box next to each statement. }\end{array}$ & \multicolumn{2}{|c|}{ Yes } & \multicolumn{2}{|c|}{ No } \\
\hline \multicolumn{5}{|l|}{$\begin{array}{l}\text { - I try to be physically active (e.g. do more walking, running, cycling, exercising, dancing, } \\
\text { practising sports, working in the garden) }\end{array}$} \\
\hline \multicolumn{5}{|l|}{$\begin{array}{l}\text { - I pay attention to my diet (e.g. having breakfast every day, eating more vegetables and fruits, } \\
\text { drinking more milk or kefir/yoghurt, limiting intake of sweets, fats, salt) }\end{array}$} \\
\hline \multicolumn{5}{|l|}{$\begin{array}{l}\text { - I pay attention to systematic self-assessments (e.g. body weight, blood pressure, } \\
\text { breasts [women], testes [men]). }\end{array}$} \\
\hline \multicolumn{5}{|l|}{ - I make sure to have good relations with my loved ones (family, friends). } \\
\hline \multicolumn{5}{|l|}{ - I ask others for help when I face a challenging problem. } \\
\hline \multicolumn{5}{|l|}{ - I find time to rest (e.g. relaxing, doing what I enjoy). } \\
\hline \multicolumn{5}{|l|}{ - I try to find positives in myself and others (e.g. students, colleagues, family, friends). } \\
\hline \multicolumn{5}{|l|}{ - I work on my ability to cope with stress, pressure. } \\
\hline $\begin{array}{l}\text { - I have given up a behaviour which is a health risk, e.g. quit smoking, stopped abusing alcohol } \\
\text { or made efforts to that effect (leave unchecked if you have not engaged in such behaviours). }\end{array}$ & & & & \\
\hline
\end{tabular}


and then describes it to the teacher. The key aspect of the technique is the conversation for which the drawing serves as a cue. The student may draw whatever she/ he wants, as much as she/he wants, and however shel he wants).

\begin{tabular}{l|l}
\hline $\begin{array}{l}\text { What do you like } \\
\text { at school? }\end{array}$ & $\begin{array}{l}\text { What don't you like } \\
\text { at school? }\end{array}$ \\
\hline - teachers & $\begin{array}{l}\text { - when teachers scream } \\
\text { - noise } \\
\text { - classmates }\end{array}$ \\
$\begin{array}{l}\text { - breaks, because I get to } \\
\text { play with cars }\end{array}$ & $\begin{array}{l}\text { go upstairs and I want to be } \\
\text { downstairs (in the basement) }\end{array}$ \\
- physical education lessons \\
- going to the day-care \\
room, lights, to the gym
\end{tabular}

Figure 4

Sample student responses

(10 years, moderate intellectual disability) given during a conversation

\begin{tabular}{l|l}
\hline $\begin{array}{l}\text { What do you like } \\
\text { at school? }\end{array}$ & $\begin{array}{l}\text { What don't you like } \\
\text { at school? }\end{array}$ \\
\hline - I am happy at school, & $\begin{array}{l}\text { - I don't like noise at school. } \\
\text { - Iga makes a lot of noise, } \\
\text { - I like writing, }\end{array}$ \\
$\begin{array}{l}\text { - I like physical education } \\
\text { lessons, music, rhythmics, } \\
\text { - I like eating, } \\
\text { - I like Maja and Tomek }\end{array}$ & \\
\hline
\end{tabular}

Figure 5.

Sample student response

(18 years, moderate intellectual disability) using the "Draw and tell" technique (drawing and response transcript)

\begin{tabular}{l|l}
\hline $\begin{array}{l}\text { What do you like } \\
\text { at school? }\end{array}$ & $\begin{array}{l}\text { What don't you like } \\
\text { at school? }\end{array}$ \\
\hline $\begin{array}{l}\text { I like learning German, } \\
\text { religion and Berna. write and } \\
\text { read count draw }\end{array}$ & $\begin{array}{l}\text { I don't like noise. I don't like } \\
\text { when children push one another }\end{array}$ \\
\hline
\end{tabular}

Figure 6 .

Sample student work

(10 years, mild intellectual disability and motor aphasia) using the "Draw and write" technique

\begin{tabular}{l|l}
\hline $\begin{array}{l}\text { WHAT DO I LIKE } \\
\text { AT SCHOOL? }\end{array}$ & $\begin{array}{l}\text { WHAT I DON'T LIKE } \\
\text { AT SCHOOL? }\end{array}$ \\
\hline Natural history, Fridays, Lunch, & Michalina, them \\
I like the natural history teacher, & together, Asia, \\
I like snowball fights, I like computers, & Mondays, Tuesdays, \\
I like physical education lessons, I like & Wednesdays, I don' \\
history, I like my friends, I like field \\
$\begin{array}{l}\text { trips, I like playing football, I like the } \\
\text { day-care room, I like playing in the } \\
\text { snow / Thursday }\end{array}$ & like to fight, I don't like \\
\hline
\end{tabular}

Figure 7.

(12 years, mild intellectual disability)
- "Draw and write": What do you like and not like at school? (the student makes drawings about a given subject and then writes captions (titles, descriptions). The teacher can help to caption the drawings).

- Written response: Write what you like and do not like at school.

The subject of the evaluation is always the same, the only difference being the data collection method. The choice of technique and number of participating students is at the discretion of the evaluation team in consultation with class teachers. One or several techniques may be used in a given class/group of students. Selection should be made on the basis of: level of cognitive and motor development of students, their communication skills, age, willingness to participate and other factors that may affect the results and reliability of the evaluation. Only students who are able to respond to questions asked in the selected way should take part in the process.

The processing of the results involves categorising the contents of drawings/responses given by the students. The following categories/dimensions have been identified: teachers and other school employees and relations with them, students and relations between them, things (objects), activities (classes, play activities, events), food and drink, locations, equipment and school yard, others.

Evaluation sheets for assessing standard fulfillment and outcomes serve to sum up the results obtained using various methods and identify key problems that require attention. There are various types of sheets.

The evaluation sheets for standards I, III, and IV contain a list of indicators with evaluation $\operatorname{method}(\mathrm{s})$ for each. An excerpt from the Evaluation Sheet for standard I is provided as illustration below (Fig. 8). All methods listed for a given indicator must be taken into account during it's evaluation.

A 4-point scale is used to assess each indicator:

- 5 pts - preferred ("optimal") state, no corrections, additions, modifications or improvements required, this is the school's strength.

- 4 pts. - some deviations from the preferred state, only a slight correction/improvement needed.

- 3 pts. - clear deviations from the preferred state, significant correction/improvement needed.

- 2 pts. - failure to achieve or unsatisfactory achievement of a given indicator, requires very significant correction/ improvement needed, this is the school's weakness. 
EVALUATION SHEET FOR STANDARD I

Dimensions and indicators (preferred, "optimal" state)

Evaluation (points)
Elements needing

improvement

(if current state

deviates from preferred one)

\begin{tabular}{|c|c|c|}
\hline \multicolumn{3}{|l|}{ 1. Including health promotion in documents and in school work and life } \\
\hline $\begin{array}{l}\text { - The school's charter (or its equivalent) states that: the school implements the HPS } \\
\text { programme; the programme is one of its priorities; health promotion includes students } \\
\text { and staff; it is consistent with the HPS concept adopted in Poland (Document analysis) }\end{array}$ & 5432 & \\
\hline $\begin{array}{l}\text {-Staff members and students' parents feel that health and well-being are important } \\
\text { at the school (Questionnaire CT, OTaS, NTS, P - question 1) }\end{array}$ & 5432 & \\
\hline $\begin{array}{l}\text { - Staff members think that the school undertakes health promoting activities addressed } \\
\text { to them (Questionnaire CT, OTaS, NTS - question 2) }\end{array}$ & 5432 & \\
\hline \multicolumn{3}{|l|}{ 2. Structure for implementing the health promoting school programme } \\
\hline $\begin{array}{l}\text { - The health promotion team includes representatives of: school management, CT, NTS, P, } \\
\text { school nurse; the tasks are set forth in writing (Document analysis, interviews) }\end{array}$ & 5432 & \\
\hline $\begin{array}{l}\text { - The school coordinator for health promotion has been appointed by the principal upon } \\
\text { request of the health promotion team; the coordinator's tasks are set forth in writing } \\
\text { (Interview with coordinator, document analysis) }\end{array}$ & 5432 & \\
\hline $\begin{array}{l}\text { - The school nurse takes part in the planning, implementation and evaluation of health } \\
\text { promotion projects at school (Interviews with nurse and principal) }\end{array}$ & 5432 & \\
\hline - The school management supports health promotion activities (Interviews, observation) & 5432 & \\
\hline
\end{tabular}

Figure 8.

Excerpt from the Evaluation Sheet for standard I: first dimension indicators

If document analysis, interview or observation is recommended to evaluate a given indicator, it is determined whether and to what extent the current state deviates from the preferred one, i.e. 5 pts. When a questionnaire is recommended for evaluation of a given indicator, response rates are converted into points using the formula described above. For some indicators, questionnaire responses for two or more groups of subjects are taken into account and the average score is calculated. Assessment of indicators helps identify those aspects which require improvements.
The purpose of the evaluation sheets for standard II is to sum up the results of the assessment of the school's social climate from the perspective of the school, parents, and students. Portions of these sheets are provided in Figures 9 and 10. In the Sheet concerning adult members of the school community, response rates are converted into points, mean scores are calculated for each dimension and jointly for all dimensions. In the Sheet regarding students, the contents of responses are assigned to individual dimensions divided into positive and negati-

EVALUATION SHEET FOR STANDARD II:

evaluation of the school's social climate from the point of view of staff and students' parents

\begin{tabular}{l|l|l|l|l}
\hline $\begin{array}{l}\text { Study group } \\
\text { number of subjects }\end{array}$ & $\begin{array}{l}\text { Dimensions } \\
\text { (item number } \\
\text { in the questionnaire) }\end{array}$ & $\begin{array}{l}\text { Evaluation: } \\
\text { mean score in } \\
\text { each dimension }\end{array}$ & $\begin{array}{l}\text { Evaluation: } \\
\text { mean score across } \\
\text { all dimensions }\end{array}$ & $\begin{array}{l}\text { Elements needing } \\
\text { improvement, } \\
\text { if current state deviates } \\
\text { from preferred one }\end{array}$ \\
\hline $\begin{array}{l}\text { Class teachers } \\
\text { number: ...... }\end{array}$ & $\begin{array}{l}\text { Opportunities to take part } \\
\text { in school life (4-5) }\end{array}$ & $\begin{array}{l} \\
\text { Relationship with and support } \\
\text { from the school management (6-9) }\end{array}$ & & \\
\hline & Relations with teachers (10-12) & & \\
\hline & $\begin{array}{l}\text { Relations with other school } \\
\text { employees (13-14) }\end{array}$ & & & \\
\hline & Relations with students' parents (15-17) & & & \\
\hline
\end{tabular}

Figure 9.

Excerpt from the Evaluation Sheet for standard II: assessment of employees and students' parents 
EVALUATION SHEET FOR STANDARD II:

what students like and do not like at school

\begin{tabular}{l|l|l|l|l}
\hline $\begin{array}{l}\text { Research } \\
\text { method: }\end{array}$ & $\begin{array}{l}\square \text { Conversation } \\
\text { Number of students } \\
\text { evaluated: ... }\end{array}$ & $\begin{array}{l}\square \text { Draw and tell } \\
\text { Number of students } \\
\text { evaluated: ... }\end{array}$ & $\begin{array}{l}\square \text { Draw and write } \\
\text { Number of students } \\
\text { evaluated: ... }\end{array}$ \\
\hline Dimensions & \multicolumn{1}{|c|}{ What do students like at school? } & $\begin{array}{l}\square \text { Written response } \\
\text { evaluated: ... }\end{array}$ \\
\hline $\begin{array}{l}\text { evachers students } \\
\text { and relations with them }\end{array}$ & $\begin{array}{l}\text { Contents (indicators) } \\
\text { of students' responses }\end{array}$ & $\begin{array}{l}\text { Number } \\
\text { of indications }\end{array}$ & $\begin{array}{l}\text { What don't students like at school? } \\
\text { of students' responses }\end{array}$ & $\begin{array}{l}\text { Number } \\
\text { of indications }\end{array}$ \\
\hline $\begin{array}{l}\text { Students and relations } \\
\text { between them }\end{array}$ & & & & \\
\hline
\end{tabular}

Figure 10

Excerpt from the Evaluation Sheet for standard II: assessment of students

ve, and frequency rates are then calculated. Some student responses may apply to more than one dimension. Categorisation relating to specific dimension(s) is done by the person conducting the evaluation.

The evaluation sheet for the assessment of outcomes is used to record data on the well-being levels at the school and health promotion activities undertaken. It's portions are provided in Figure 11. This sheet includes data from responses to open questions in the questionnaires (factors that have positive and negative effects on the well-being of each group at the school).

Each evaluation sheet concludes with a summary containing the key problem that needs to be solved as soon as possible. For example, some of the following key problems were identified at one of the pilot study schools:

- Insufficient number of training sessions and availability of information about the health promoting school concept among non-teaching staff (standard I).
- Lack of opportunities for participation in the life and workings of the school from the perspective of staff (standard II).

- Lack of systematic initiatives regarding oral hygiene of students (standard III).

- Insufficient competences of staff with respect to caring for their own health and conducting health education for students (standard IV).

\section{CONCLUSION}

The project to develop HPSS standards along with the self-evaluation procedure and tools was undertaken in response to the needs and expectations of special schools. Our efforts were based on the concept of health promotion at mainstream schools (Woynarowska \& Woynarowska-Sołdan, 2019) and nearly 30 years' experience of implementation in Poland. The rationale has been that the procedure for creating a HPS at a mainstream

\section{OUTCOME EVALUATION SHEET}

\begin{tabular}{|c|c|c|c|c|}
\hline \multicolumn{5}{|l|}{ Well-being at school } \\
\hline \multirow[t]{2}{*}{$\begin{array}{l}\text { Study group } \\
\text { number of people surveyed }\end{array}$} & \multirow[t]{2}{*}{$\begin{array}{l}\text { Mean } \\
\text { score }\end{array}$} & \multicolumn{2}{|c|}{$\begin{array}{l}\text { The most important or frequently mentioned factors } \\
\text { affecting well-being (regards responses to open questions) }\end{array}$} & \multirow[t]{2}{*}{$\begin{array}{l}\text { Reasons for not answering } \\
\text { open questions }\end{array}$} \\
\hline & & POSITIVELY & NEGATIVELY & \\
\hline \multicolumn{5}{|l|}{$\begin{array}{l}\text { Class teachers } \\
\text { number: ....... }\end{array}$} \\
\hline \multicolumn{5}{|c|}{ [...] Taking action to strengthen health } \\
\hline \multirow[t]{2}{*}{$\begin{array}{l}\text { Study group number } \\
\text { of people surveyed }\end{array}$} & & \multicolumn{2}{|c|}{ Rate of yes responses } & $\begin{array}{l}\text { Activities to strengthen } \\
\text { health undertaken }\end{array}$ \\
\hline & & \multicolumn{2}{|c|}{ THE MOST OFTEN } & THE LEAST OFTEN \\
\hline $\begin{array}{l}\text { Class teachers } \\
\text { number: ....... }\end{array}$ & & & & \\
\hline
\end{tabular}


and special school should be as similar as possible. The assumption being that, apart from certain differences in these schools' operations, they had a lot in common. We came to the conclusion that preserving similar operating procedures would facilitate the work of school's and HPSS's regional network coordinators while encouraging the exchange of ideas and collaboration between special, mainstream, and integrated schools.

The HPSS standards adopt the whole school approach to health promotion, which is the first pillar of the SHE network (2009). The standards and self-evaluation procedure are compatible with the European Standards and Indicators for Health Promoting Schools (Bada et al., 2019), and take into account the recommendations of the SHE network regarding HPS planning, implementation, and evaluation.

The Action Research-based process of developing standards and self-evaluation procedures involved many individuals, at all stages with consulting at the national, regional, and school levels. This was work carried out "with people" (democratic approach reflecting the values adopted in the SHE network) (SHE, 2009) in order to solve a problem they found important (the approach "from people to the problem" employed in health promotion) (Baric, 1992). By participating in this process, special school teachers became owners of the HPSS concept, and as such are better equipped and motivated to implement it.

A sure success was the way in which students were included in the evaluation of the school's atmosphere/ social climate. Four techniques for asking students what they did and did not like at school were proposed. The choice of technique to elicit students' responses is at the discretion of each school and depends on students' abilities. Some students were unable to participate in the study using those techniques. In those cases, self-evaluation was limited to teaching and non-teaching staff and students' parents. It should be noted that involving students with intellectual disabilities in the self-evaluation research has significant limitations and findings are indicative rather than definitive. Nevertheless, the decision was to, as far as possible, ask students and take their answers into account. This is a reflection of respect and equal treatment, as well as an expression of confidence in their abilities. The analysis of data obtained from students in the pilot study showed that their responses contained many elements that enabled evaluators to identify positive and negative aspects of school functionality and look for solutions to emerging problems. It is important that students' input is analysed by individuals who know them well. It should be noted that the proposed techniques are suitable for use at integrated and mainstream schools attended by students with mild intellectual disabilities.

The relatively small number of schools that participated in the pilot study may be considered a limitation in the process of developing the HPSS self-evaluation procedure and tools. The majority of methods used were subjective. The pilot study revealed a tendency to inflate assessment results, even though this was a voluntary self-evaluation undertaken only for the benefit of a given school's community and no comparisons were made between schools (persons conducting self-evaluations wanted their school to "do well").

The HPSS model, standards, and the procedure and tools for self-evaluation and it's functioning were compiled in a manual for special schools (educating children and adolescents with intellectual disabilities) and people supporting their health promoting activities (Woynarowska-Sołdan et al., 2020), which contains a comprehensive description of the concepts and strategies for establishing HPSS in Poland. The Ministry of National Education's approval was obtained for special schools to apply for the National Health Promoting School Certificate. Thanks to the project, today in Poland there are three related proposals for implementing the concept of health promotion at educational institutions of various types: kindergartens, mainstream schools, and special schools. This creates the opportunity to popularise the concept throughout the entire education system, as recommended in the WHO and UNESCO initiative: "Making Every School a Health Promoting School" (WHO, UNESCO, n.d.).

\section{ACKNOWLEDGEMENT}

None.

\section{DISCLOSURE STATEMENT}

No potential conflict of interest

was reported by the authors.

\section{FUNDING}

None. 


\section{REFERENCES}

McAteer, M. (2013). Action Research in education. Sage.

Bada, E., Darlington, E., Masson, J., \& Santos, R.N. (2019). European Standards and Indicators for Health Promoting Schools. Schools for Health in Europe Network Foundation. Retrieved 20 July 2020 from: https://www.schoolsforhealth.org/resources/materials-and-tools/standards-indicators

Baric, L. (1992). Promoting Health. New Approaches and Developments. Journal of the Institute of Health Education, 30(1), 6-16. https://doi.org/10.1080/03073289.1992.10805752 (original paper published online 2014).

Clift S., \& Jensen B. B. (Eds.) (2005) The Health Promoting School: International Advances in Theory, Evaluation and Practice. Danish University of Education Press. As cited in Busch, V., Laninga-Wijnen, L., Schrijvers, A. J. P. \& De Leeuw, J. R. J. (2017). Associations of health behaviors, school performance and psychosocial problems in adolescents in the Netherlands. Health Promotion International, 32 (2), 280-291. https://doi.org/10.1093/heapro/dav058

Czerepanik-Walczak, A. (2010). Badanie w działaniu. In S. Pałka (Ed.), Podstawy metodologii badań w pedagogice (pp. 319-337). Gdańskie Wydawnictwo Psychologiczne.

Dadaczynski, K., Jensen, B. B., Grieg Viig, N., Sormunen, M., von Seeleen, J., Kuchma, V. \&Vilaça, M. T. (2019). Health, well-being and education: a building a sustainable future. The Moscow Statement on Health Promoting Schools. Retrieved 20 July 2020 from: https://www.schoolsforhealth.org/resources/conference-statements/moscow-statement

GUS (2019). Oświata i wychowanie w roku 2018/2019. Główny Urząd Statystyczny.

ORE (2020). Procedura nadawania Krajowego Certyfikatu Przedszkole Promujące Zdrowie i Krajowego Certyfikatu Szkoła Promująca Zdrowie. Ośrodek Rozwoju Edukacji. Retrieved 20 July 2020 from: www.ore.edu.pl/2010/09/krajowy-certyfikat-szkoy-promujcej-zdrowie

SHE (2009). Better schools through health (2009), the Third European Conference on Health Promoting Schools, 15-17 June 2009. Retrieved 20 July 2020 from: https://www.schoolsforhealth.org/resources/conference-statements/vilnius-resolution

SHE (2013). School health promotion: evidence for effective action, SHE Factsheet 2, CBO SHE secretariat. Retrieved 20 July 2020 from: https://www.schoolsforhealth.org/sites/default/files/editor/fact-sheets/she-factsheet-2-school-health-promotion-evidence.pdf

Stewart Burgher, M., Barnekow Rasmussen, V., \& Rivett, D. (1999). The European Network of Health Promoting Schools the alliance of education and health. International Planning Committee.

WHO (1986). Ottawa Charter for Health Promotion. World Health Organization.

WHO, UNESCO (n.d). Global Standards for Health Promoting Schools. Concept note. Retrieved 20 July 2020 from: www.who.int/maternal_child_adolescent/adolescence/globa-standards-for-health-promoting-schools-who-unesco.pdf?ua=1

Woynarowska, B. (2013). Preparing and planning for the health promoting schools development in Poland. In O. Samdal, \& L. Rowling (Eds.), The implementation of health promoting schools. Exploring the theories of what, why and how (pp. 126-133). Routledge.

Woynarowska, B., \& Sokołowska, M. (2006). A national network for developing and evaluating health promoting schools in Poland. In V. Barnekow, G. Buijs, S. Clift, B. B. Jensen, P. Paulus, D. Rivett \& I. Young (Eds.), Health-promoting schools: A resource for developing indicators (pp. 118-133). International Planning Committee.

Woynarowska, B., \& Sokołowska, M. (2009). Poland: The Health Promoting School National Certificate. In Ch. V. Whitmaan, \& C. A. Aldinger (Eds.), Case studies in global school health promotion (pp. 213-224). Springer Science \& Business Media, LLC.

Woynarowska, B., \& Woynarowska-Sołdan, M. (Eds.) (2019). Szkoła promująca zdrowie. Podręcznik dla szkół i osób wspierających ich działania w zakresie promocji zdrowia. Ośrodek Rozwoju Edukacji.

Woynarowska-Sołdan, M. (2015). Szkoła promująca zdrowie w Europie w świetle dokumentów czterech europejskich konferencji. Kwartalnik Pedagogiczny, 1(235), 97-111.

Woynarowska-Sołdan, M. (2016). Projekt „Promocja zdrowia pracowników szkoły”. Podstawy teoretyczne i koncepcja. Chowanna, 2(45), 239-259.

Woynarowska-Sołdan, M. (2018). Implementation trial of school staff health promotion: Polish experiences. Health Promotion International, 34(5), 1-12. https://doi.org/10.1093/heapro/day068

Woynarowska-Sołdan, M., \& Woynarowska, B. (2017). Przedszkole promujące zdrowie. Poradnik dla przedszkoli i osób wspierających ich działania w zakresie promocji zdrowia. Ośrodek Rozwoju Edukacji.

Woynarowska-Sołdan, M., Woynarowska, B., \& Danielewicz, D. (2020). Szkoła specjalna promująca zdrowie. Podręcznik dla szkół specjalnych kształcących dzieci i młodzież z niepełnosprawnością intelektualną i osób wspierających ich działania w zakresie promocji zdrowia. Ośrodek Rozwoju Edukacji. 